\title{
DECONTAMINATION INTERVENTIONS FOR THE REUSE OF SURGICAL MASK PERSONAL PROTECTIVE EQUIPMENT (PPE): A PROTOCOL FOR A SYSTEMATIC REVIEW
}

PRISMA-P (Preferred Reporting Items for Systematic review and Meta-Analysis Protocols) 2015 checklist [1]

\begin{tabular}{|c|c|c|c|}
\hline Section/Topic & $\begin{array}{c}\text { Item } \\
\text { No. }\end{array}$ & Checklist Item & Protocol Information \\
\hline \multicolumn{4}{|c|}{ Administrative Information } \\
\hline \multicolumn{4}{|c|}{ Title } \\
\hline Identification & $1 \mathrm{a}$ & $\begin{array}{l}\text { Identify the report as a } \\
\text { protocol of a systematic } \\
\text { review }\end{array}$ & $\begin{array}{l}\text { Decontamination Interventions for the Reuse of } \\
\text { Surgical Mask Personal Protective Equipment } \\
\text { (PPE): A Protocol for a Systematic Review }\end{array}$ \\
\hline Update & $1 b$ & $\begin{array}{l}\text { If the protocol is for an } \\
\text { update of a previous } \\
\text { systematic review, } \\
\text { identify as such }\end{array}$ & This is an original systematic review. \\
\hline Registration & 2 & $\begin{array}{l}\text { If registered, provide the } \\
\text { name of the registry } \\
\text { (e.g., PROSPERO) and } \\
\text { registration number in the } \\
\text { abstract }\end{array}$ & $\begin{array}{l}\text { The systematic review protocol was registered } \\
\text { with the International Prospective Register of } \\
\text { Systematic Reviews (PROSPERO) on } 8 \text { April } \\
2020 \text { (registration number pending). The } \\
\text { protocol will be uploaded in pre-print to Open } \\
\text { Science Framework (OSF). }\end{array}$ \\
\hline \multicolumn{4}{|r|}{ (2) } \\
\hline Contact & $3 a$ & $\begin{array}{l}\text { Provide name, ORCID, } \\
\text { institutional affiliation, } \\
\text { and e-mail address of all } \\
\text { protocol authors; provide } \\
\text { physical mailing address } \\
\text { of corresponding author }\end{array}$ & $\begin{array}{l}\text { Corresponding author: Karen Choong } \\
\text { (choongk@mcmaster.ca) } \\
\text { Department of Pediatric Critical Care, } \\
\text { McMaster University } \\
\text { McMaster Children's Hospital, Room 3E20 } \\
1280 \text { Main Street West, Hamilton, Ontario, } \\
\text { Canada, L8N 3Z5 } \\
\text { ORCID: 0000-0002-4608-4508 }\end{array}$ \\
\hline & & & $\begin{array}{l}\text { David Zorko (zorkodj@mcmaster.ca) } \\
\text { McMaster University } \\
\text { ORCID: 0000-0002-6971-8542 }\end{array}$ \\
\hline & & & $\begin{array}{l}\text { James Dayre McNally (dmcnally@cheo.on.ca) } \\
\text { Children's Hospital of Eastern Ontario } \\
\text { ORCID: 0000-0001-8103-9967 }\end{array}$ \\
\hline & & & $\begin{array}{l}\text { Katie O'Hearn (kohearn@cheo.on.ca) } \\
\text { Children's Hospital of Eastern Ontario } \\
\text { Research Institute } \\
\text { ORCID: } 0000-0002-1149-2843\end{array}$ \\
\hline & & & $\begin{array}{l}\text { Lindsey Sikora (lindsey.sikora@uottawa.ca) } \\
\text { University of Ottawa } \\
\text { ORCID: 0000-0002-9715-8634 }\end{array}$ \\
\hline
\end{tabular}




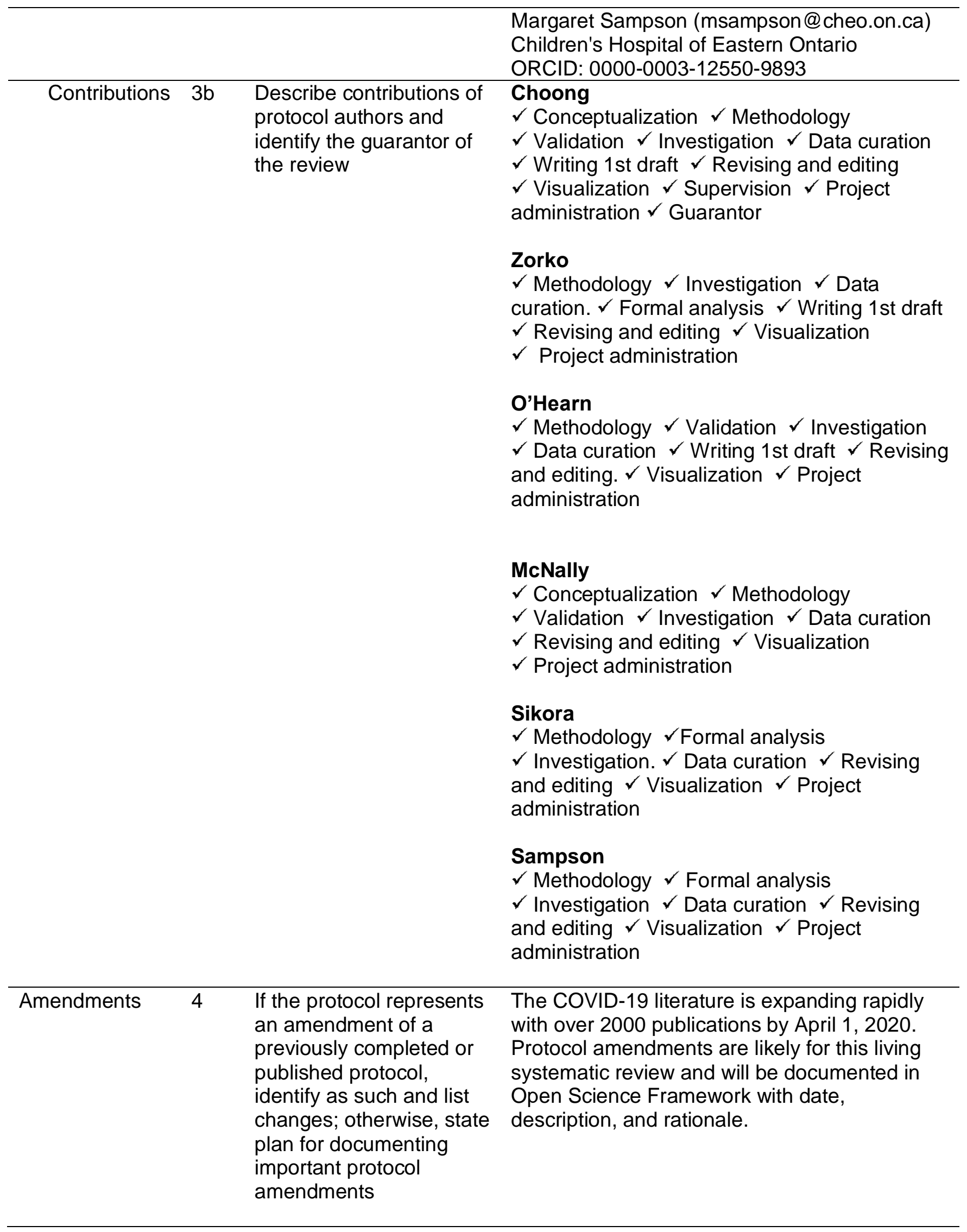




\begin{tabular}{|c|c|c|c|}
\hline \multicolumn{4}{|r|}{ Th } \\
\hline Sources & $5 a$ & $\begin{array}{l}\text { Indicate sources of } \\
\text { financial or other support } \\
\text { for the review }\end{array}$ & This research has received no specific funding. \\
\hline Sponsor & $5 b$ & $\begin{array}{l}\text { Provide name for the } \\
\text { review funder and/or } \\
\text { sponsor }\end{array}$ & $\begin{array}{l}\text { This research does not have a funder or } \\
\text { sponsor. }\end{array}$ \\
\hline $\begin{array}{l}\text { Role of } \\
\text { sponsor/ } \\
\text { funder }\end{array}$ & $5 c$ & $\begin{array}{l}\text { Describe roles of } \\
\text { funder(s), sponsor(s), } \\
\text { and/or institution(s), if } \\
\text { any, in developing the } \\
\text { protocol }\end{array}$ & $\begin{array}{l}\text { This research does not have a funder or } \\
\text { sponsor. }\end{array}$ \\
\hline \multicolumn{4}{|l|}{ Introduction } \\
\hline Rationale & 6 & $\begin{array}{l}\text { Describe the rationale for } \\
\text { the review in the context } \\
\text { of what is already known }\end{array}$ & $\begin{array}{l}\text { As the global spread of novel coronavirus } \\
\text { (SARS-CoV-2) escalates, the high demand for } \\
\text { PPE has created shortages of this equipment } \\
\text { globally and prompted the need to ensure } \\
\text { appropriate stewardship and develop strategies } \\
\text { to conserve supply. N95 filtering respirators } \\
\text { (FFRs) are recommended for healthcare } \\
\text { providers caring for suspected or confirmed } \\
\text { coronavirus disease (COVID-19) patients } \\
\text { requiring airborne precautions and for aerosol- } \\
\text { generating medical procedures [2]; therefore, } \\
\text { N95 FFRs are most commonly needed for front } \\
\text { line workers in an acute care or inpatient } \\
\text { setting. }\end{array}$ \\
\hline & & & $\begin{array}{l}\text { In contrast, surgical masks are recommended } \\
\text { for droplet/contact precautions and therefore } \\
\text { needed for healthcare providers not only in the } \\
\text { inpatient setting, but in outpatient settings, } \\
\text { COVID-19 assessment centres, long-term care } \\
\text { facilities and community care settings. Surgical } \\
\text { masks are a recommended PPE for healthcare } \\
\text { providers when droplet precautions are } \\
\text { required, such as during the care of suspected } \\
\text { or confirmed COVID-19 patients, and for the } \\
\text { care of the general patient population in areas } \\
\text { where community spread of COVID-19 is of } \\
\text { concern [2]. Surgical masks are not only for the } \\
\text { protection of healthcare providers, but are also } \\
\text { to protect the dissemination of droplets from } \\
\text { patients shedding the virus, and hence are also } \\
\text { recommended for use in patients suspected or } \\
\text { confirmed to have COVID-19 [2]. Due to these } \\
\text { broad and common place applications, surgical } \\
\text { mask rationing and conservation is therefore a } \\
\text { priority to ensure adequate supply during a } \\
\text { pandemic. }\end{array}$ \\
\hline
\end{tabular}


Surgical masks are designed for single use.

Because of severe shortages of surgical masks

and N95 FFRs during the COVID-19 pandemic, several methods have been considered to decontaminate and allow the reuse of singleuse PPE, such as hydrogen peroxide vapour and microwave irradiation [3]. A recent systematic review suggests that ultraviolet germicidal irradiation (UVGI) using UV-C light can decontaminate N95 FFRs without affecting their performance [4]. It is unclear however, whether these methods are effective and nondamaging for single-use surgical masks.

\begin{tabular}{|c|c|c|c|}
\hline Objectives & 7 & $\begin{array}{l}\text { Provide an explicit } \\
\text { statement of the } \\
\text { question(s) the review } \\
\text { will address with } \\
\text { reference to participants, } \\
\text { interventions, } \\
\text { comparators, and } \\
\text { outcomes (PICO) }\end{array}$ & $\begin{array}{l}\text { The objective of this systematic review is to } \\
\text { identify and synthesize data from published } \\
\text { studies evaluating interventions used to } \\
\text { decontaminate or treat surgical mask PPE for } \\
\text { the purposes of reuse. }\end{array}$ \\
\hline \multicolumn{4}{|l|}{ Methods } \\
\hline Eligibility criteria & 8 & $\begin{array}{l}\text { Specify the study } \\
\text { characteristics (e.g., } \\
\text { PICO, study design, } \\
\text { setting, time frame) and } \\
\text { report characteristics } \\
\text { (e.g., years considered, } \\
\text { language, publication } \\
\text { status) to be used as } \\
\text { criteria for eligibility for } \\
\text { the review }\end{array}$ & $\begin{array}{l}\text { Population: Surgical face mask PPE or their } \\
\text { components } \\
\text { Intervention: Any intervention used to } \\
\text { decontaminate, sterilize or treat surgical face } \\
\text { masks (applied either before or after their use), } \\
\text { to enable the reuse of the mask as PPE. } \\
\text { Comparator: There is no specified comparator } \\
\text { group. Stand-alone criteria have been set for } \\
\text { mask performance (penetration) and we will } \\
\text { primarily compare against these benchmarks. } \\
\text { Outcome: Efficacy of the intervention, as } \\
\text { measured by any one of the following: } \\
\text { 1. Mask filtration performance (i.e. effect on } \\
\text { droplet or particle penetration and airflow } \\
\text { resistance) } \\
\text { 2. Removal of viral or bacterial load } \\
\text { 3. Mask appearance or physical degradation } \\
\text { 4. Adverse effects as experienced by the } \\
\text { wearer (e.g. skin irritation) } \\
\text { 5. Feasibility of the intervention (e.g. time, cost, } \\
\text { resource utilization) } \\
6 . \text { Clinical infection prevention rates of } \\
\text { healthcare providers wearing decontaminated } \\
\text { masks }\end{array}$ \\
\hline & & & $\begin{array}{l}\text { Study designs: We will include English or } \\
\text { French original publications examining any } \\
\text { method of surgical mask PPE decontamination. }\end{array}$ \\
\hline
\end{tabular}


We will also include systematic reviews of any method of surgical mask PPE decontamination. We will exclude studies that evaluated interventions isolated to N95 FFRs. Editorial reviews, narrative reviews, grey literature, clinical practice guidelines, patents and books will be excluded.

\begin{tabular}{|c|c|c|}
\hline $\begin{array}{l}\text { Information } \\
\text { sources }\end{array}$ & 9 & $\begin{array}{l}\text { Describe all intended } \\
\text { information sources (e.g., } \\
\text { electronic databases, } \\
\text { contact with study } \\
\text { authors, trial registers, or } \\
\text { other grey literature } \\
\text { sources) with planned } \\
\text { dates of coverage }\end{array}$ \\
\hline
\end{tabular}

The following databases will be searched by two health sciences librarians (LS and MS): Medline and Medline in Process via OVID, Embase Classic + Embase via OVID, Cochrane CENTRAL and Global Health via CAB Direct. The search strategy was developed in Medline, and then translated into the other databases, as appropriate (see Protocol Section 10). All databases will be searched from their dates of inception on April 8, 2020. The language was restricted to English or French, with no other publication restrictions. Three journals will also be handsearched, as they were particularly relevant to the review but are not indexed in any of the databases used: Journal of the International Society for Respiratory Protection, Aerosol Science and Technology and the Journal of Engineered Fibers and Fabrics. A search of Google Scholar (April 8, 2020) through Publish or Perish will be screened until 50 consecutive apparently irrelevant records are found. The WHO database on COVID-19 of April 27, 2020 will be downloaded and searched within Reference Manager. Disaster Lit: Database for Disaster Medicine and Public Health, MedRxiv and OSF Preprints will be searched April 8, 2020 and records pertaining to decontamination will be selected and downloaded. Reference Lists of eligible studies will be examined.

Given the rapidly evolving landscape of PPE literature during the COVID-19 pandemic, we plan to update the literature search regularly (i.e. minimum every 2 weeks, maximum every 2 months) for new, relevant evidence on as it becomes available (living systematic review) [5]. This will ensure that new evidence is promptly synthesized and made available to policy makers to guide PPE conservation protocols. 


\begin{tabular}{|c|c|c|c|}
\hline \multicolumn{2}{|l|}{ Search strategy } & $\begin{array}{l}\text { Present draft of search } \\
\text { strategy to be used for at } \\
\text { least one electronic } \\
\text { database, including } \\
\text { planned limits, such that } \\
\text { it could be repeated }\end{array}$ & 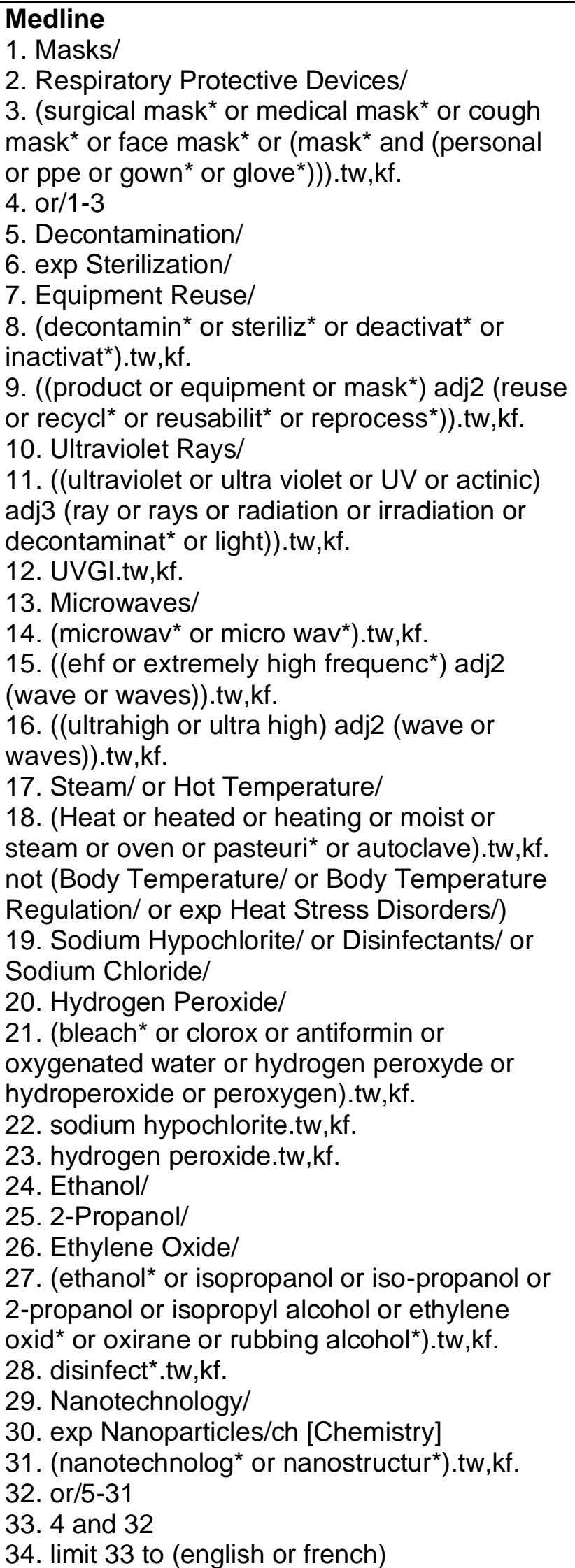 \\
\hline
\end{tabular}




\begin{tabular}{|c|c|c|c|}
\hline \multicolumn{4}{|l|}{ Study Records } \\
\hline $\begin{array}{l}\text { Data } \\
\text { management }\end{array}$ & $11 a$ & $\begin{array}{l}\text { Describe the } \\
\text { mechanism(s) that will be } \\
\text { used to manage records } \\
\text { and data throughout the } \\
\text { review }\end{array}$ & $\begin{array}{l}\text { Records will be downloaded into Endnote for } \\
\text { duplicate removal and exported to insightScope } \\
\text { for screening. Data abstraction will be } \\
\text { performed using REDCap for study details and } \\
\text { methodology. A second stage using piloted } \\
\text { spreadsheets will be used to obtain outcome } \\
\text { data. }\end{array}$ \\
\hline $\begin{array}{l}\text { Selection } \\
\text { process }\end{array}$ & $11 b$ & $\begin{array}{l}\text { State the process that } \\
\text { will be used for selecting } \\
\text { studies (e.g., two } \\
\text { independent reviewers) } \\
\text { through each phase of } \\
\text { the review (i.e., } \\
\text { screening, eligibility, and } \\
\text { inclusion in meta- } \\
\text { analysis) }\end{array}$ & $\begin{array}{l}\text { Screening will be performed in two steps (title } \\
\text { and abstract, full text) against inclusion criteria } \\
\text { by two independent reviewers. Consensus } \\
\text { and/or resolution of conflicts will be performed } \\
\text { by a third reviewer, where necessary. }\end{array}$ \\
\hline $\begin{array}{l}\text { Data } \\
\text { collection } \\
\text { process }\end{array}$ & $11 \mathrm{c}$ & $\begin{array}{l}\text { Describe planned } \\
\text { method of extracting data } \\
\text { from reports (e.g., } \\
\text { piloting forms, done } \\
\text { independently, in } \\
\text { duplicate), any processes } \\
\text { for obtaining and } \\
\text { confirming data from } \\
\text { investigators }\end{array}$ & $\begin{array}{l}\text { A test set of } 50 \text { citations will be used to } \\
\text { evaluate the inclusion/exclusion criteria. The } \\
\text { test set will be created by a member of the } \\
\text { investigative team and verified by a second } \\
\text { member. All reviewers who contribute to } \\
\text { screening will first perform the test set, and } \\
\text { must achieve a sensitivity of } \geq 80 \% \text { before they } \\
\text { are given access to the full set of study } \\
\text { records. Reviewers who do not achieve } \geq 80 \% \\
\text { sensitivity will be provided with additional } \\
\text { training and repeat a second test set. If } \geq 80 \% \\
\text { sensitivity is achieved on the repeat test set, } \\
\text { the reviewer will be given to access to the full } \\
\text { set of study records. }\end{array}$ \\
\hline & & & $\begin{array}{l}\text { Data will be abstracted onto REDCap forms by } \\
\text { two independent reviewers in duplicate. } \\
\text { Consensus and/or resolution of conflicts will be } \\
\text { performed by a third reviewer, where } \\
\text { necessary. The data abstraction form will be } \\
\text { piloted by at least two members of the } \\
\text { investigative team against a total of five eligible } \\
\text { studies. }\end{array}$ \\
\hline Data items & 12 & $\begin{array}{l}\text { List and define all } \\
\text { variables for which data } \\
\text { will be sought (e.g., PICO } \\
\text { items, funding sources), } \\
\text { any pre-planned data } \\
\text { assumptions and } \\
\text { simplifications }\end{array}$ & $\begin{array}{l}\text { a) Study demographics } \\
\text { - Author name and contact information } \\
\text { - Title } \\
\text { - Country of origin } \\
\text { - Journal and year of publication } \\
\text { b) Study design } \\
\text { - Type of study (e.g. Pre and post, post } \\
\text { - } \quad \text { Conly) } \\
\text { - Controlled versus uncontrolled }\end{array}$ \\
\hline
\end{tabular}


c) PPE tested

- Mask type and model

- Full mask or components

- Type of pathogen and method of mask contamination

d) Decontamination intervention

- Method of mask treatment or decontamination (e.g. microwave/heat methods, UV germicidal irradiation)

- Timing (i.e. before or after mask use, both)

- Frequency, duration, intensity (as applicable to intervention) of decontamination protocol

- Method of supporting/suspending masks

- Drying/post-decontamination process

e) Outcomes

- Outcome measurement tool (e.g. penetration test used, airflow resistance test used)

- Penetration (absolute percentage, change relative to baseline)

- Airflow resistance and pressure drop

- Absolute and relative change in pathogen number

- Absolute and relative change in clinical infection rate

- Observations of physical degradation or odour

- Adverse events experienced by the user following wear of the treated mask (e.g. skin irritation, shortness of breath)

- Time, cost, and resources required for decontamination protocol

f) Modifying factors

- Intervention and outcome evaluated against soiling measures

Outcomes and prioritization
13 List and define all outcomes for which data will be sought, including prioritization of main and additional outcomes, with rationale
The main outcomes for which data will be sought are:

1. Percent filter particle penetration (primary outcome)

2. Airflow resistance (absolute values and change pre- and post-use and intervention)

3. Viral or bacterial load on the mask surface (absolute and relative change, when comparator group was included)

4. Mask degradation/physical appearance

5. User adverse event rate 
6. Feasibility, defined as outcomes related to time, cost, and resource utilization for the intervention

7. Clinical infection prevention rate (absolute and relative change, when comparator group was included)

\begin{tabular}{lll}
\hline $\begin{array}{l}\text { Risk of bias in } \\
\text { individual }\end{array}$ & 14 & $\begin{array}{l}\text { Describe anticipated } \\
\text { methods for assessing } \\
\text { studies }\end{array}$ \\
& risk of bias of individual \\
& studies, including \\
& whether this will be done \\
& at the outcome or study \\
& level, or both; state how \\
& this information will be \\
& used in data synthesis
\end{tabular}

Risk of bias will be ascertained at the study level and reported in the manuscript. The impact of risk of bias on the summarized evidence will be addressed in the discussion section of the manuscript.

Risk of bias will be assessed using standard tools (e.g. Cochrane risk of bias tool), if applicable. Otherwise, we will consider the following factors as supportive of low risk:

- Population: Application of decontamination intervention to identical mask lot

- Study design: Controlled study or pre/post design

- Methodology: Application of identical study procedures between arms other than intervention

- Outcome: assessors blinded to study arm or outcome assessed objectively (result provided by a machine)

\begin{tabular}{lcl}
\hline Data synthesis $15 a$ & $\begin{array}{l}\text { Describe criteria under } \\
\text { which study data will be } \\
\text { quantitatively } \\
\text { synthesized }\end{array}$
\end{tabular}

1. Penetration and resistance outcomes: Data will need to be available from at least three independent studies using approved testing methods to consider quantitative synthesis.

2. Viral or bacterial decontamination:

Significant heterogeneity is expected in methodology related to pathogen type (virus versus bacteria) and method of evaluation of decontamination (culture versus PCR). We will quantitatively synthesize this outcome if similar data is provided from three studies using concordant pathogen and testing. 3. Mask degradation (fibre or other mask components)/physical appearance: It is expected that studies will subjectively evaluate this outcome, and thus significant heterogeneity is expected in the evaluation of physical characteristics. We will quantitatively synthesize this outcome if similar data is provided from three studies using approved, objective testing methods to consider quantitative synthesis. 
4. User adverse event rate: Significant heterogeneity is expected in the methodology related to method of decontamination and adverse event measured. We will quantitatively synthesize this outcome if similar data is provided from three studies evaluating a concordant decontamination method and evaluating the same adverse event.

5. Feasibility: Significant heterogeneity is expected in the methodology related to method of decontamination and choice and measurement of a feasibility outcome. We will quantitatively synthesize this outcome if similar data is provided from three studies evaluating a concordant decontamination method and the same feasibility outcome.

6. Clinical infection prevention rate: Significant heterogeneity is expected in methodology related to pathogen type (virus versus bacteria) and method of evaluation of decontamination (culture versus PCR). We will quantitatively synthesize this outcome if similar data is provided from three studies using concordant pathogen and testing.

$15 \mathrm{~b}$ If data are appropriate for quantitative synthesis, describe planned summary measures, methods of handling data, and methods of combining data from studies, including any planned exploration of consistency (e.g., l2, Kendall's tau)

For the particle penetration and airflow resistance outcomes, the data is anticipated to be primarily presented as an absolute value. If presented as a percent change, and sufficient data is provided, we will calculate the absolute value. Prior to pooling data, we will perform a test of statistical heterogeneity using $I_{2}$ tests. Random effects meta-analysis will be employed to present the pooled absolute value post intervention and relative change (from control or no treatment arm).

Significant heterogeneity could be anticipated with the methods and outcomes related to contamination and decontamination. To account for differences in methods (viral load, application and retrieval from mask) we will report and pool results using log change (in addition to absolute value or change). Again, prior to pooling the results we will perform a test of statistical heterogeneity using $I_{2}$ tests. Random effects meta-analysis will be utilized.

When required, meta-analyses will be updated by use of Whitehead's trial sequential analyses (alpha 0.05; beta 0.80) for living systematic reviews [6]. 


\section{5c Describe any proposed} additional analyses (e.g., analyses, metaregression) sensitivity or subgroup

The primary indication for this work was the current pandemic related to SARS-CoV-2. Given the likely acute evolving nature of literature regarding PPE during the COVID-19 pandemic, data synthesis will be updated with every search cycle. The date of the last search and corresponding details of new evidence will be included with every update of the living systematic review in PROSPERO. Rules for incorporating new studies will follow published recommendations [5]:

1. If no new studies are found, the date of the search and indication of no additional evidence will be documented.

2. If new studies are found, the analyses will be after consultation with a clinical expert (KC, JDM) considering the amount and quality of the new evidence and its potential impact on PPE decision-making. If the new evidence is not sufficient to trigger an updated analysis and publication, the date of the search, details of new evidence, and justification for delayed analysis will be documented. If the new evidence is deemed sufficient, an updated analysis and publication will be produced.

Additional analyses are as follows:

1. For the synthesis and presentation of decontamination results we will perform a separate analysis limiting to studies that evaluate viral pathogens specifically, where possible.

2. If sufficient data permits (at least three studies) we will describe and quantitatively synthesize the data for low risk of bias studies.

\begin{tabular}{llll}
\hline 15d & $\begin{array}{l}\text { If quantitative synthesis } \\
\text { is not appropriate, } \\
\text { describe the type of } \\
\text { summary planned }\end{array}$ & $\begin{array}{l}\text { If there is insufficient quantity or quality of data } \\
\text { or the methods are sufficiently heterogenous } \\
\text { the study findings will be presented } \\
\text { descriptively in tables and text. }\end{array}$ \\
\hline Meta-bias(es) $16 \quad \begin{array}{l}\text { Specify any planned } \\
\text { assessment of meta- } \\
\text { bias(es) (e.g., publication } \\
\text { bias across studies, } \\
\text { selective reporting within } \\
\text { studies) }\end{array}$ & $\begin{array}{l}\text { Based on the anticipated small size of the } \\
\text { available literature (approximately 10 studies) } \\
\text { and limited variability in study sample sizes } \\
\text { generally observed in } \\
\text { laboratory studies, no statistical test of } \\
\text { publication bias are planned. }\end{array}$ \\
\hline
\end{tabular}




\begin{tabular}{lcll}
\hline $\begin{array}{l}\text { Confidence in } \\
\text { cumulative }\end{array}$ & 17 & $\begin{array}{l}\text { Describe how the } \\
\text { strength of the body of } \\
\text { evidence }\end{array}$ & $\begin{array}{l}\text { The cumulative body of evidence regarding the } \\
\text { reuse and decontamination of surgical mask } \\
\text { assessed (e.g., GRADE) }\end{array}$ \\
& $\begin{array}{l}\text { PPE will be evaluated using the following } \\
\text { domains: 1) Study quality, 2) Risk of bias, 3) } \\
\text { Precision, 4) Consistency, and 5) Indirectness }\end{array}$ \\
\hline
\end{tabular}

\section{REFERENCES:}

1. Moher D, Shamseer L, Clarke M, et al. Preferred reporting items for systematic review and meta-analysis protocols (PRISMA-P) 2015 statement. Syst Rev. 2015;4:1.

2. Ontario Health. Personal Protective Equipment (PPE) use during the COVID-19 Pandemic. Recommendations on the use and conservation of PPE from Ontario Health. Toronto: Ontario Ministry of Health, 2020.

3. European Centre for Disease Prevention and Control. Cloth masks and mask sterilisation as options in case of shortage of surgical masks and respirators. Stockholm: ECDC, 2020.

4. O'Hearn K, Gertsman S, Sampson M, et al. Decontaminating N95 masks with Ultraviolet Germicidal Irradiation (UVGI) does not impair mask efficacy and safety: A Systematic Review. OSF Preprints. April 8, 2020.

5. Elliott JH, Synnot A, Turner T, et al. Living systematic review: 1. Introduction-the why, what, when, and how. J Clin Epidemiol. 2017;91:23-30.

6. Simmonds, M., et al., Living systematic reviews: 3 . Statistical methods for updating metaanalyses. J Clin Epidemiol. 2017;91:38-46. 